\title{
A checklist of invertebrates from Norwegian caves and mines
}

\author{
Eivind Ostbye' and Stein-Erik Lauritzen²
}

Østbye E and Lauritzen S-E. 2013. A checklist of invertebrates from Norwegian caves and mines. Fauna norvegica 33: 35-51.

The invertebrates hitherto registered from Norwegian caves and mines are presented in a checklist. Each species is listed with localities, cavity type with altitude, total length and depth, and also minimum age ka (i.e. in units of 1000 years) if available. The species from each recorded taxa are listed in tables, with reference to the specific cave or mine where it is recorded, and to relevant publications. Taxa are classified according to their hypogean environment as trogloxenes, habitual or accidental, troglofiles and troglobites based on existing information. In total, 244 species were recorded representing 14 higher taxa. Insecta and Collembola together dominate with $85 \%$ of the recorded species, while Diptera alone stand for $42 \%$ of the species. The invertebrate fauna in Norwegian caves and mines are relatively poor compared to what is found further south in Europe.

doi: 10.5324/fn.v33i0.1585. Recieved: 2013-05-06. Accepted: 2013-11-12. Published online: 2013-12-20.

Keywords: Limestone caves, cave and mine fauna, invertebrates, Norway, checklist

1. Ringeriksveien 580, N-3410 Sylling, Norway.

2. Quaternary Uranium-Series Laboratory, Department of Earth Science, University of Bergen, Allégaten 41, N-5007 Bergen, Norway.

Corresponding author: Eivind Østbye

E-mail: eivind.ostbye@ibv.uio.no

\section{INTRODUCTION}

A general introduction to Norwegian speleology is given in Lauritzen \& Østbye (1994) and Lauritzen (2010), with a short description of caving history, caves and karst, biospeleology and vertebrate remains in caves. Relatively few surveys have been conducted in order to investigate the invertebrate fauna in Norwegian caves and mines, most of which are of short observation time (Hippa et al.1984a, b, 1985a, b, 1986, 1988a, b; Hippa \& Koponen 1988; Dolmen \& Arnekleiv 1990; Arnekleiv \& Dolmen 1992), only a few encompass studies through several seasons (Østbye et al. 1987; Kjærandsen 1992, 1993; Lien et al. 1996; Lien 1997). This paper presents an up to date checklist of known invertebrate taxa and species in the country according to published reports.

Species that occur in the hypogean (under-ground) environment are categorised after the Schiner-Racovitza system (Jefferson 1976, 1983) in three categories:
1. Trogloxenes, defined as species that never spend their whole life cycle in caves. Many species roost there or use the caves seasonally, mostly in winter for hibernation but in some cases for aestivation during the summer, while other only uses the caves as resting places during short periods. Generally they feed outside the cave. This category is further divided in two subcategories, accidental and habitual.

2. Troglofiles, defined as species that can live permanent in caves and establish reproducing populations here, but they also occur in the epigean (above-ground/on the surface) environment.

3. Troglobites, defined as obligate cave-dwellers; these are the animals which often (but not always) show the characteristic cave-modifications as loss of pigment and reduction of eyes.

As spelean ecosystems, the Norwegian caves may be divided, according to their energy flux (Heaton 1986; Østbye et al. 1987; 
Werker \& Werker 2006) into two main categories:

1. Open systems; connected directly to the surface, with rivers or brooks entering through discrete openings.

2. Infiltration systems; which are fed by ground water or seepage water from overlying material.

\section{METHODS}

The majority of reports come from north-Norwegian caves, which is quite natural as the majority of caves in Norway are situated in this part of the country (Figure 1). The faunal elements found in mines are scarcer; however, they are included here because the knowledge of immigration of animals to artificial cavities provides important information of the ecological history of cave animals. The location (in UTM coordinates), morphology and habitat characteristics of the investigated caves and mines are given in Table 1. The number of taxa (class and order) and species are summarised in Table 5. Detailed list of species recorded are presented in Table 2. The investigations by Kjærandsen $(1992,1993)$ on Diptera recorded in Norwegian caves and mines are in addition presented in Tables 3 and 4, grouped on the different types of cavities.

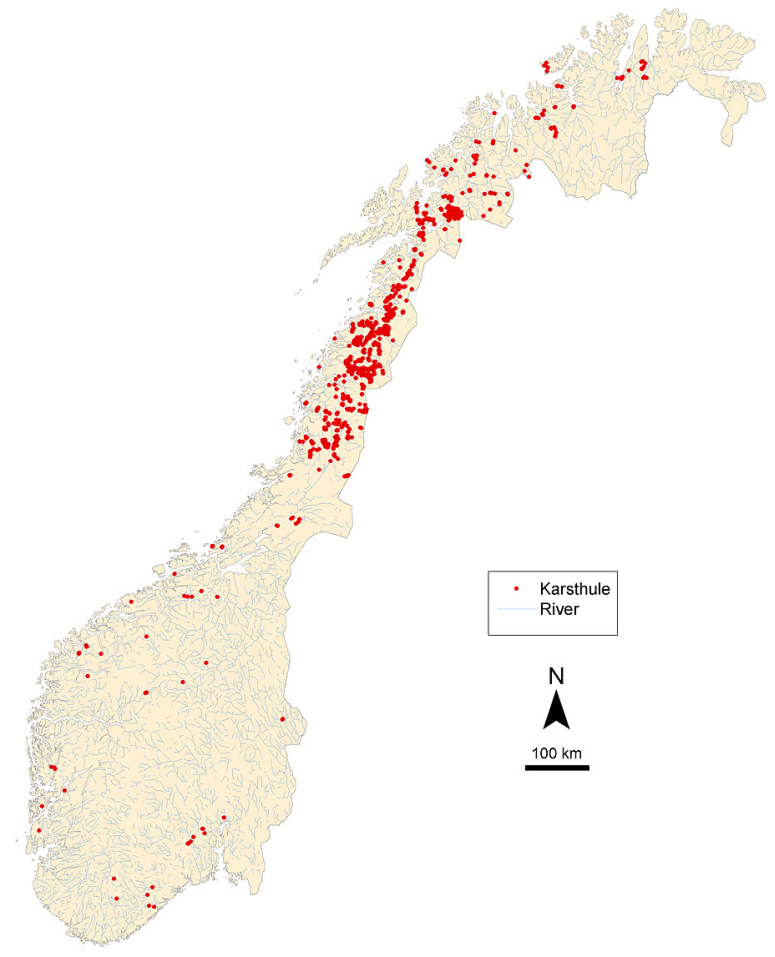

Figure I. Distribution of karst caves in Norway. After Lauritzen (2010). Reproduced with permission from Vigmostad \& Bjørke (Tun forlag).

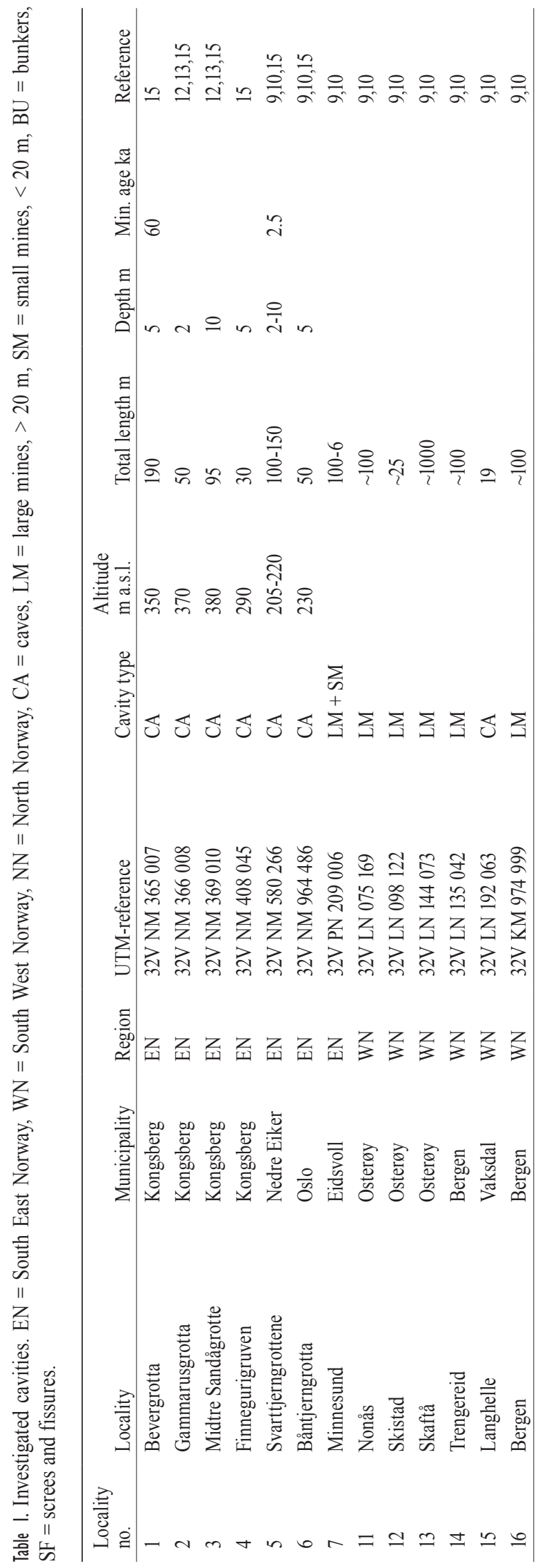




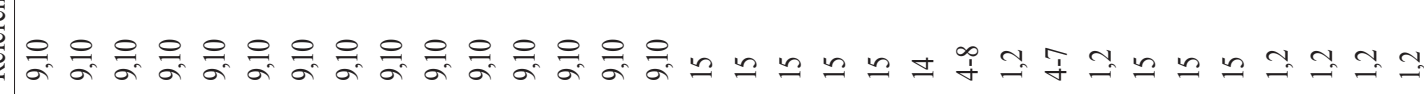

$\stackrel{2}{\pi}$

:

$\stackrel{2}{2}$

으응

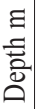

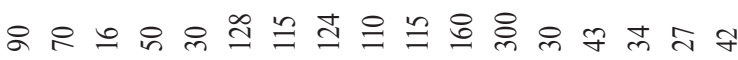

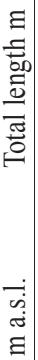

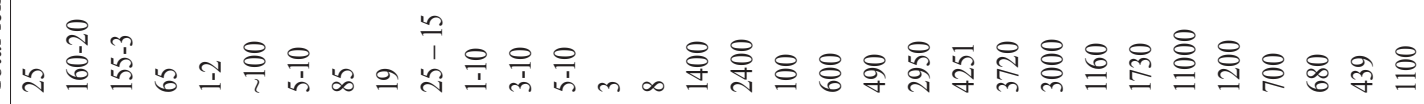

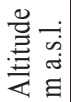

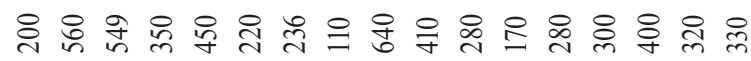

$\sum_{i=1}^{0} \sum$

$\sum_{i}$

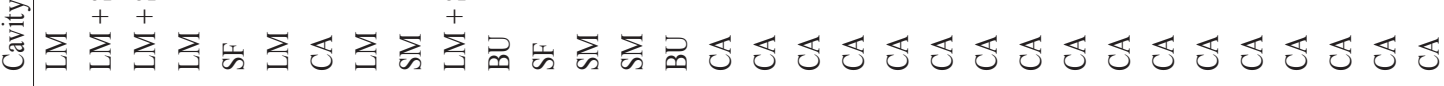

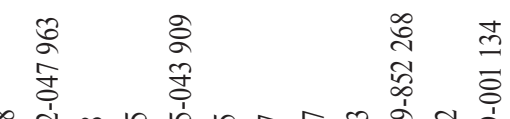

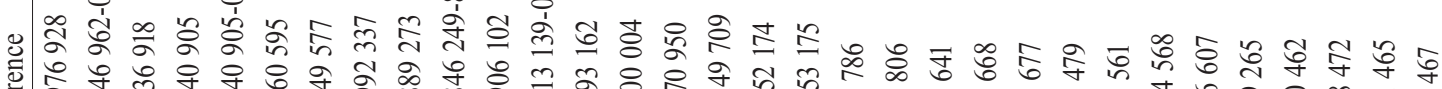

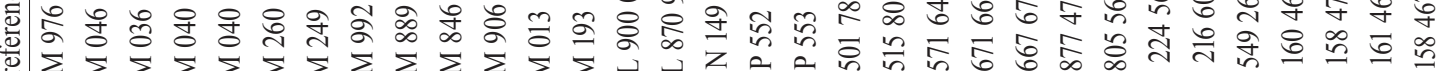

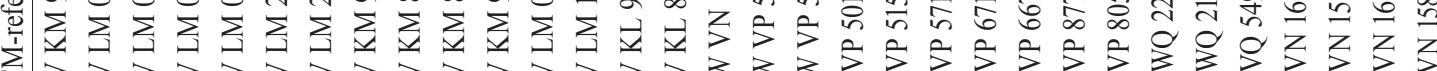

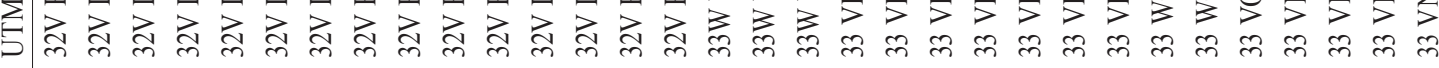

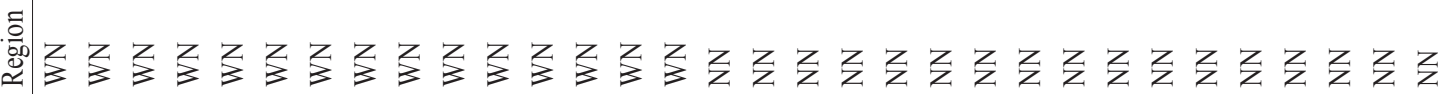

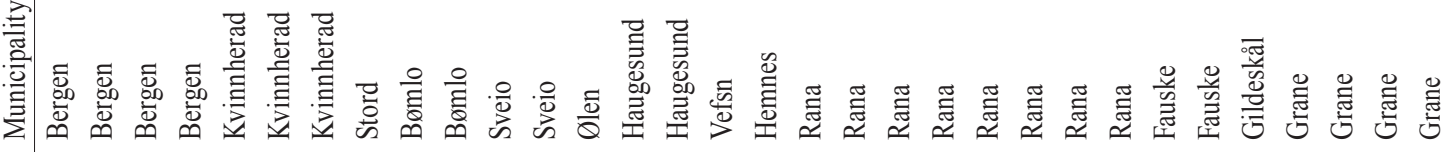

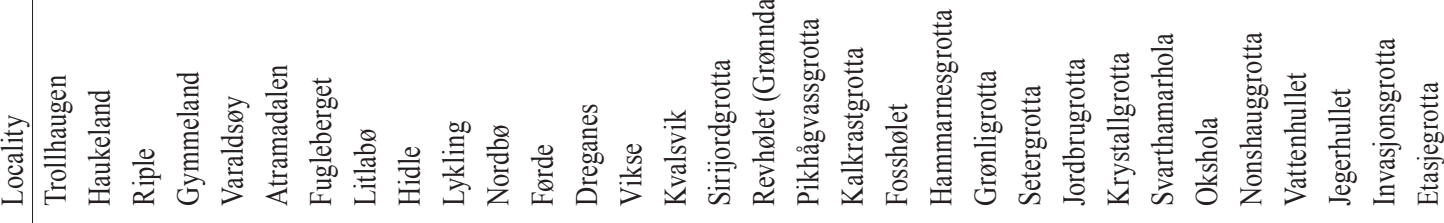




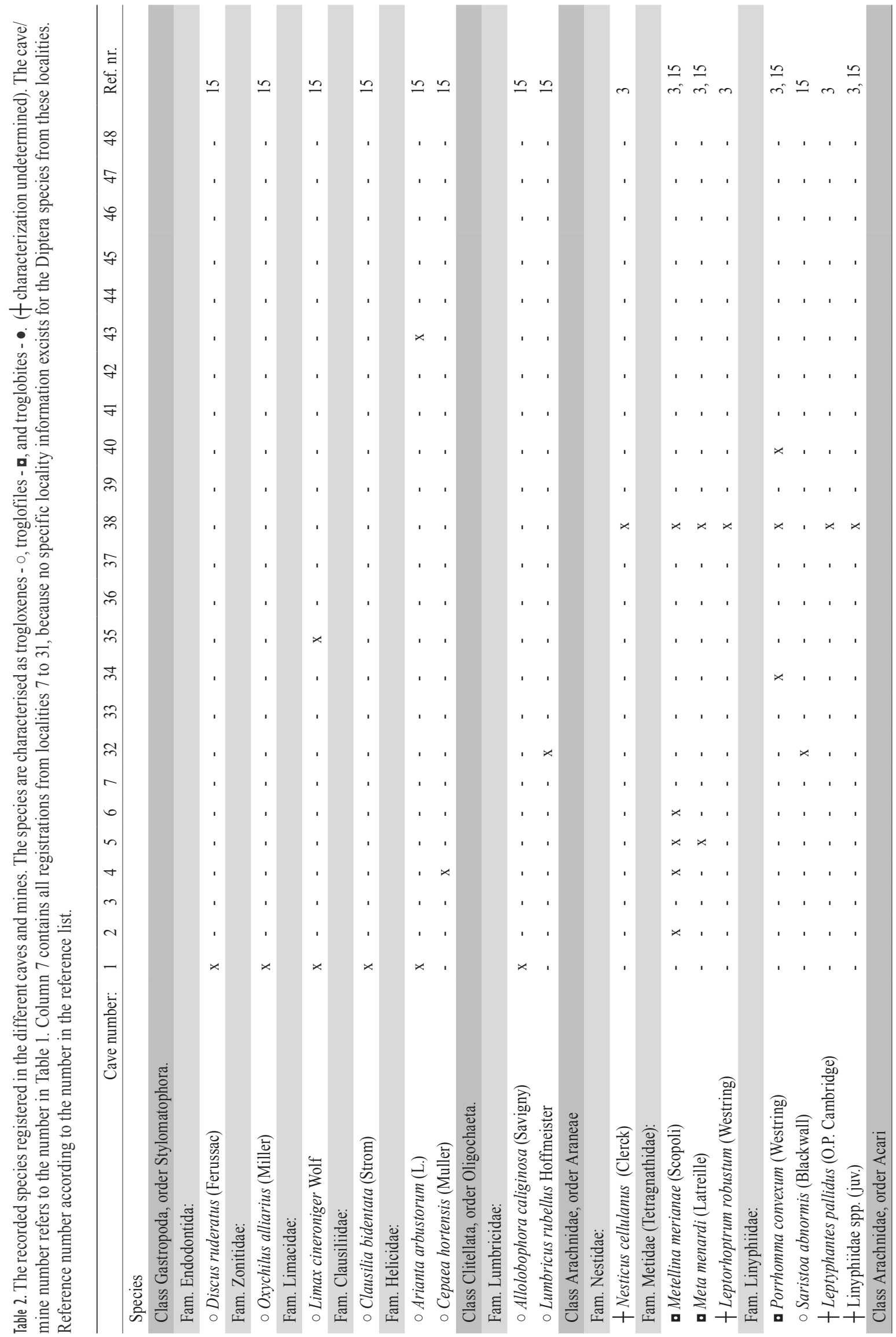




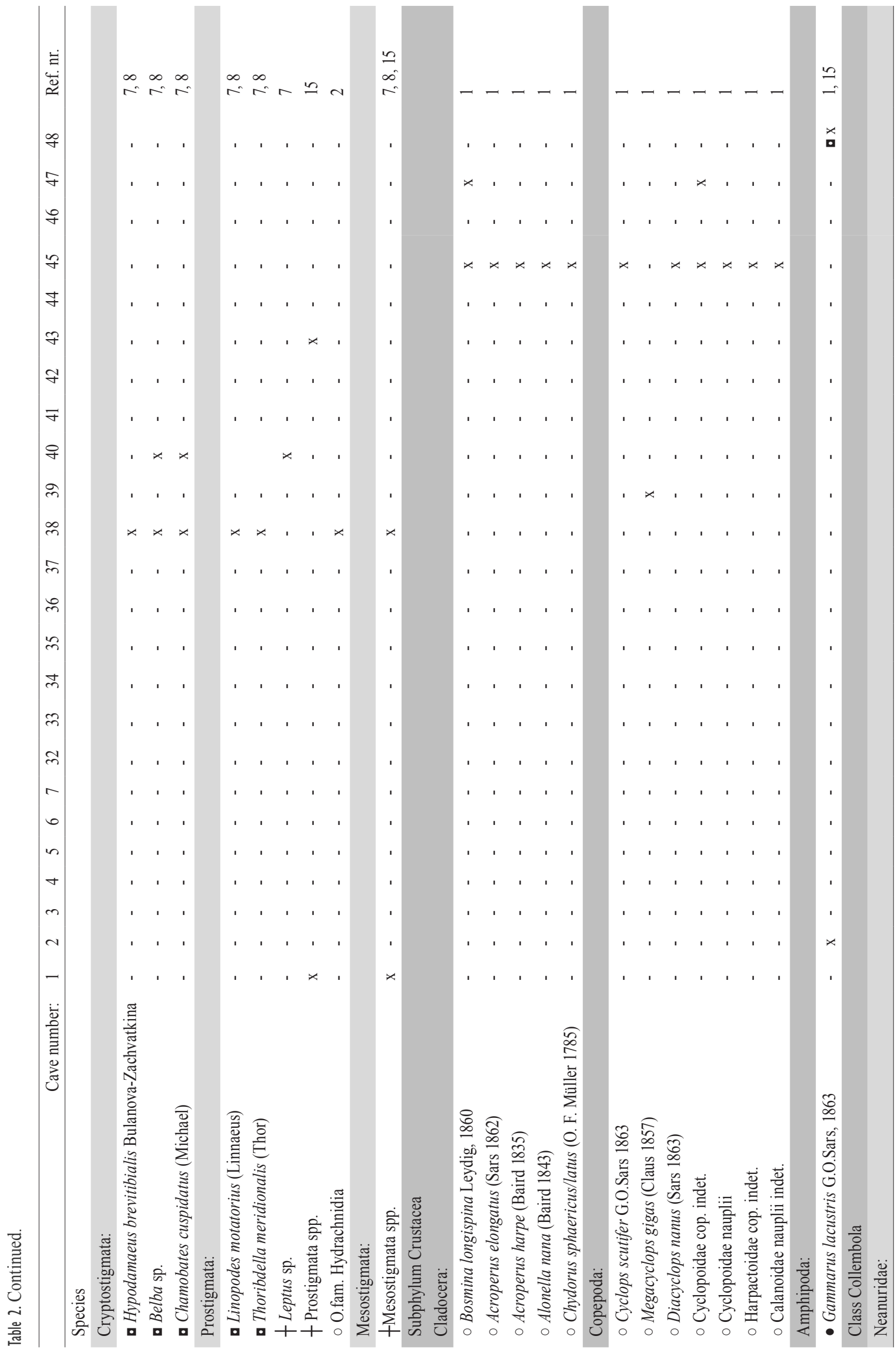




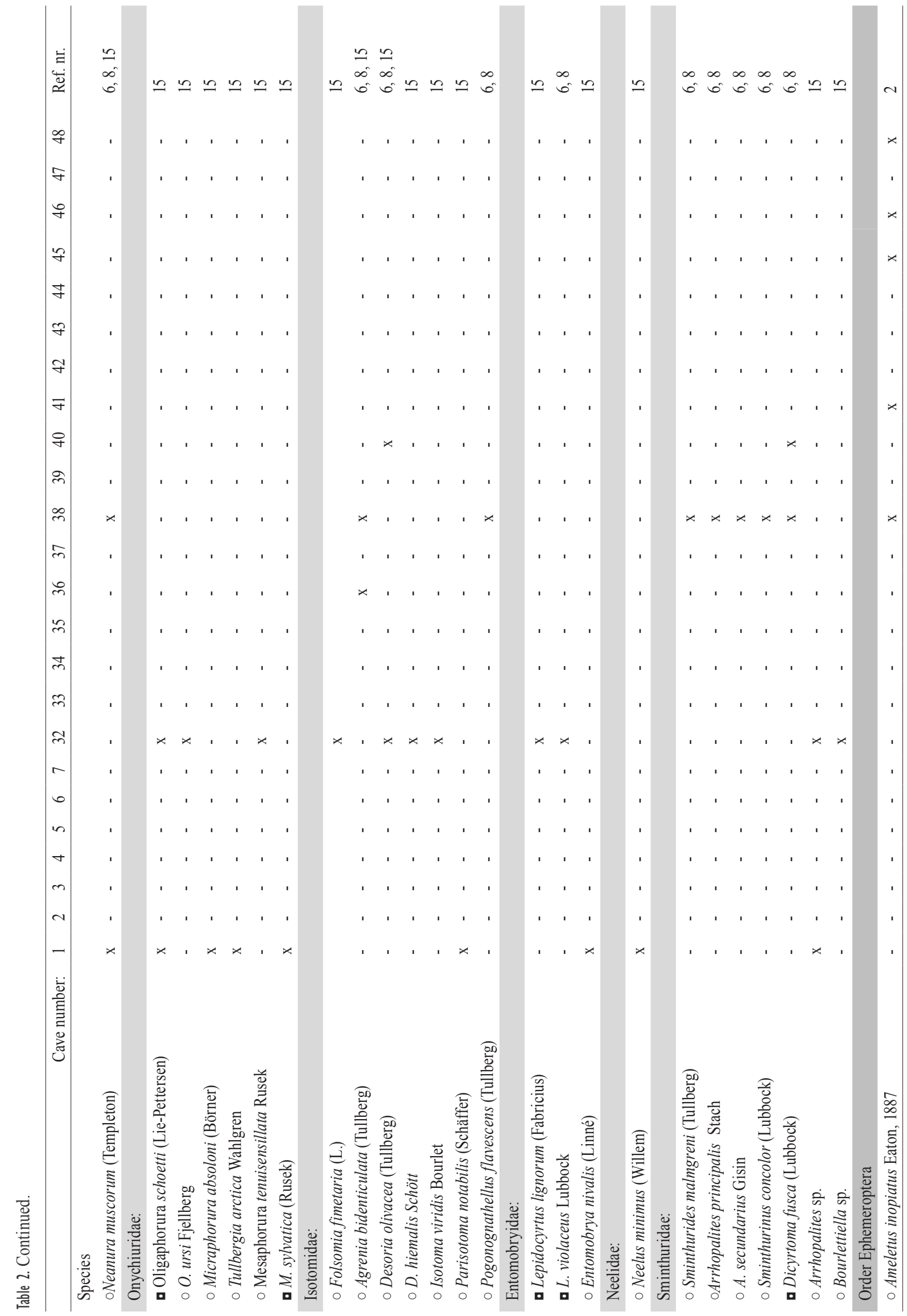




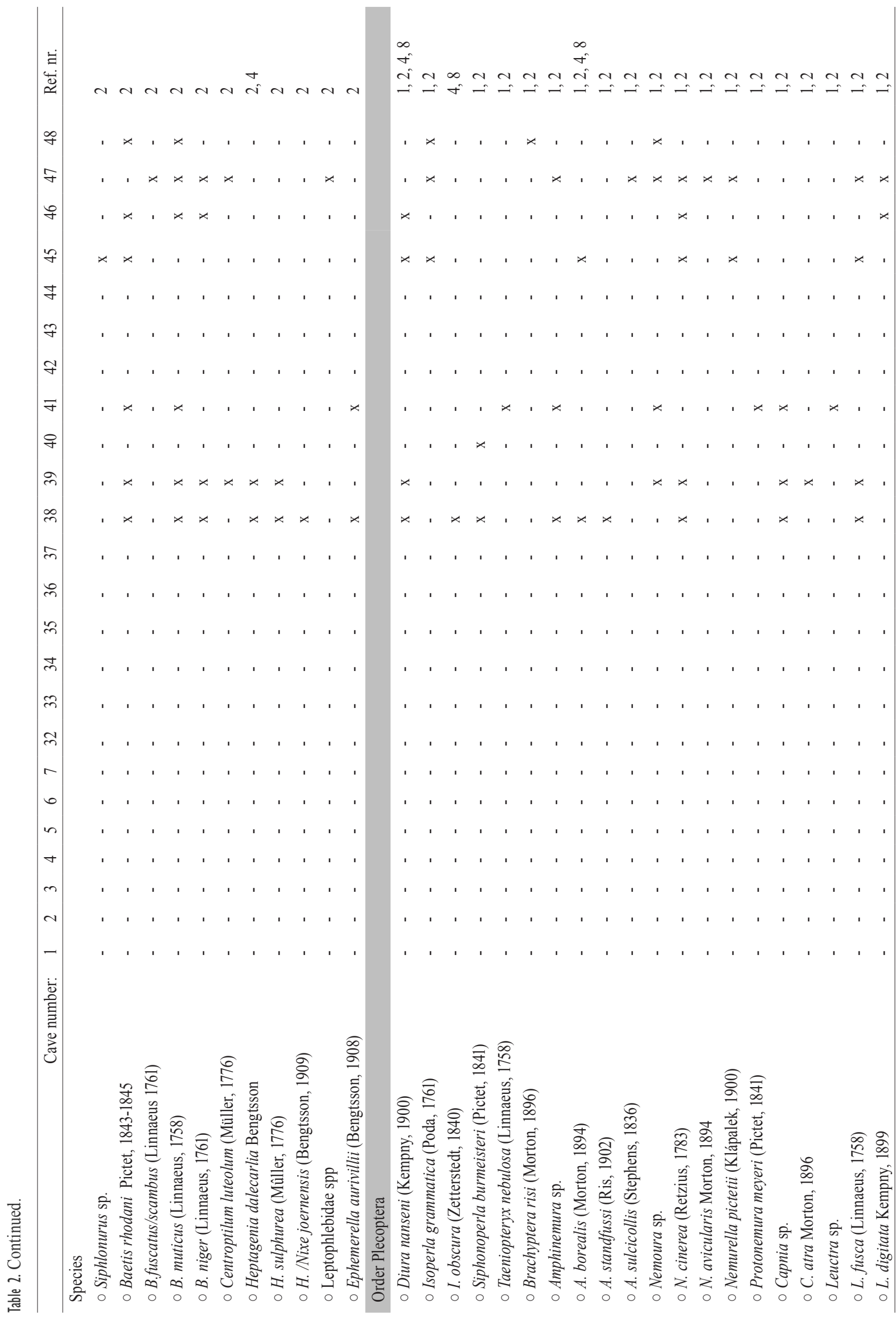




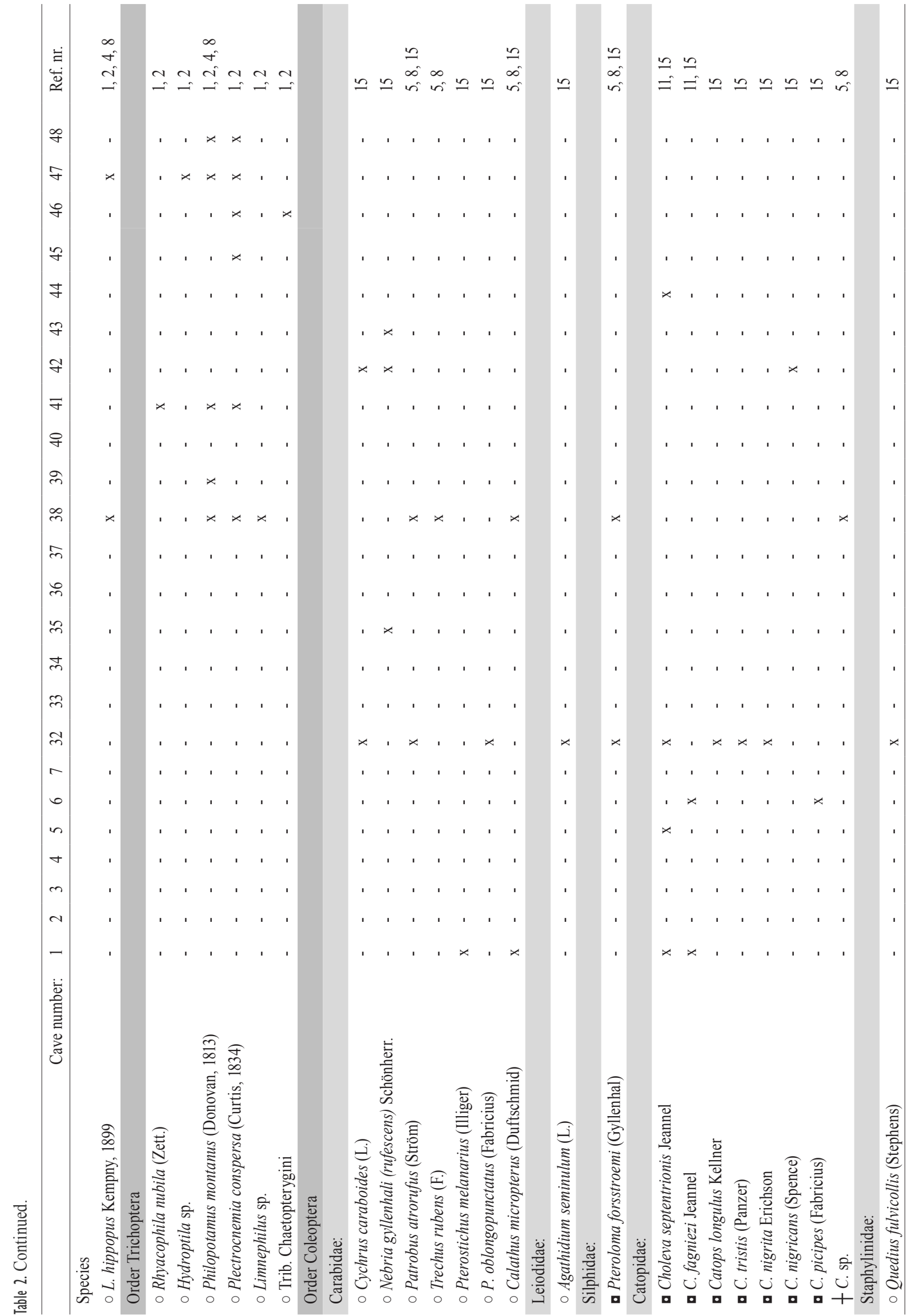




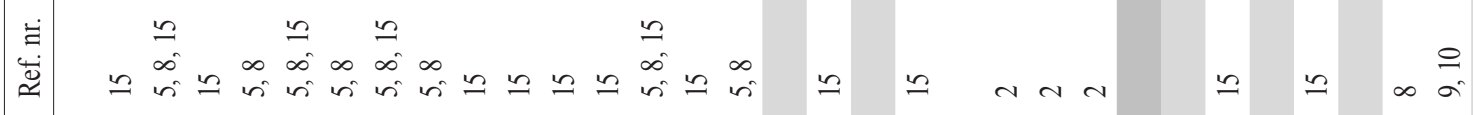

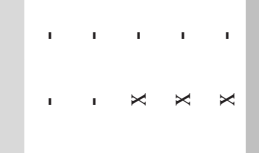




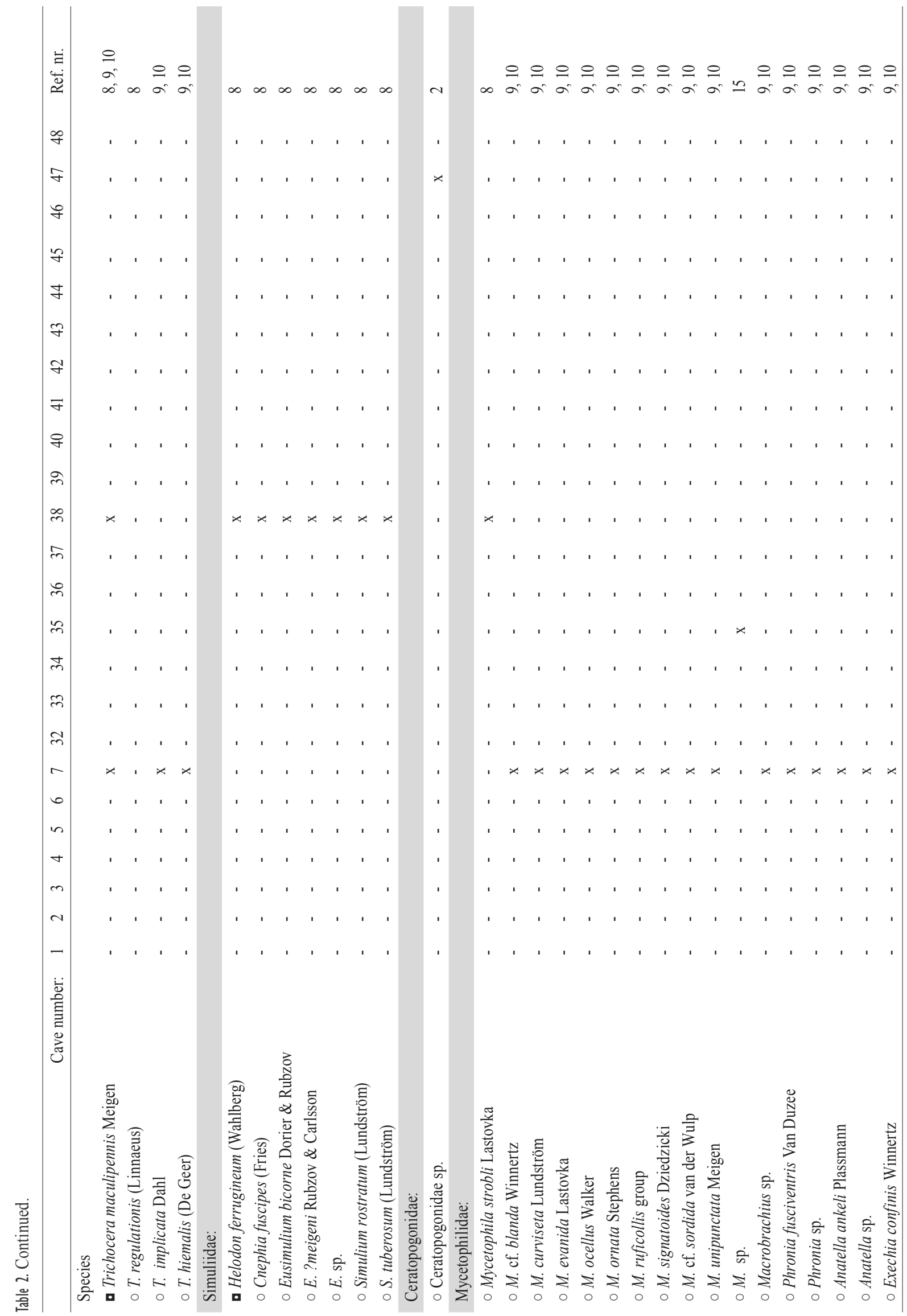




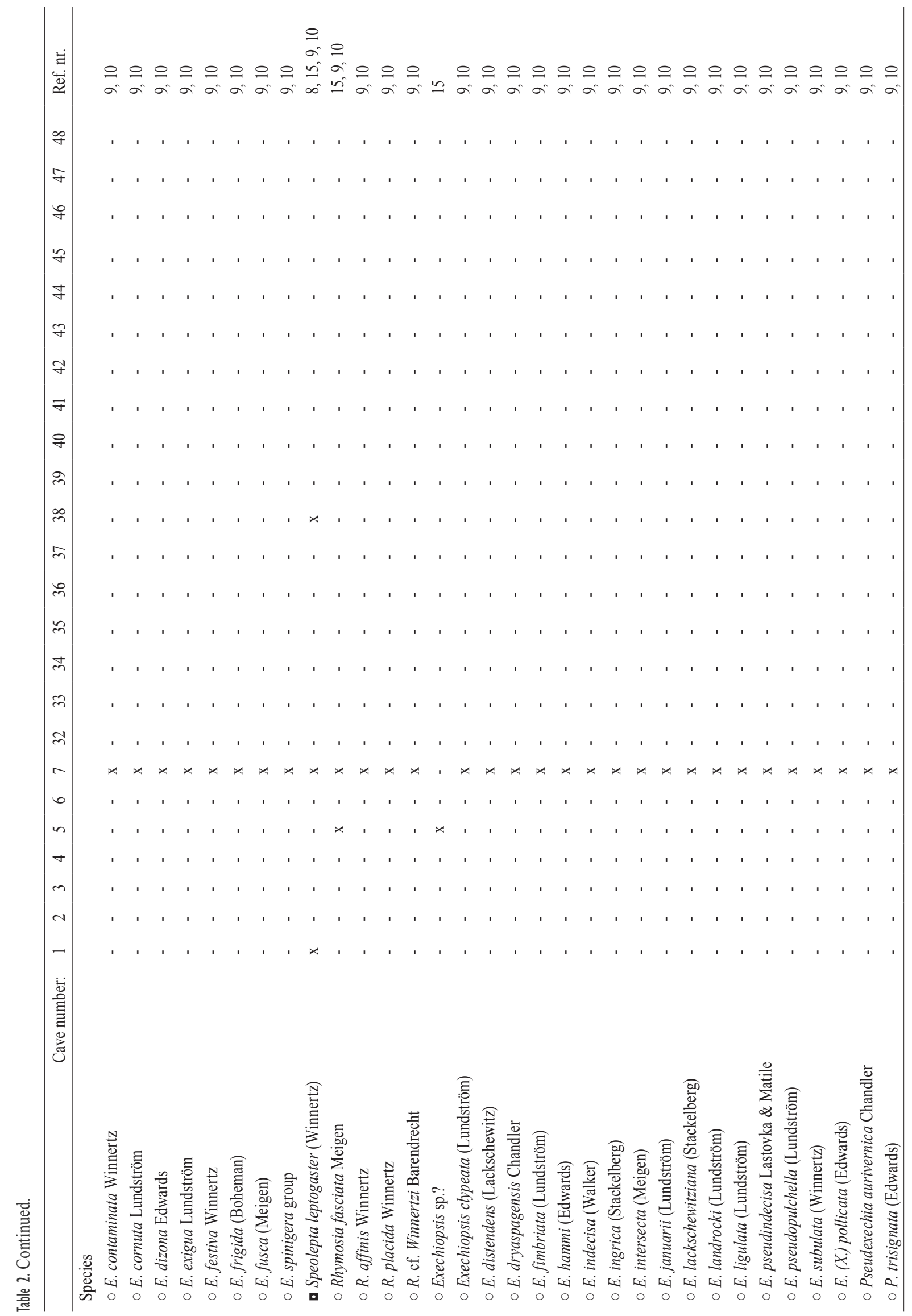




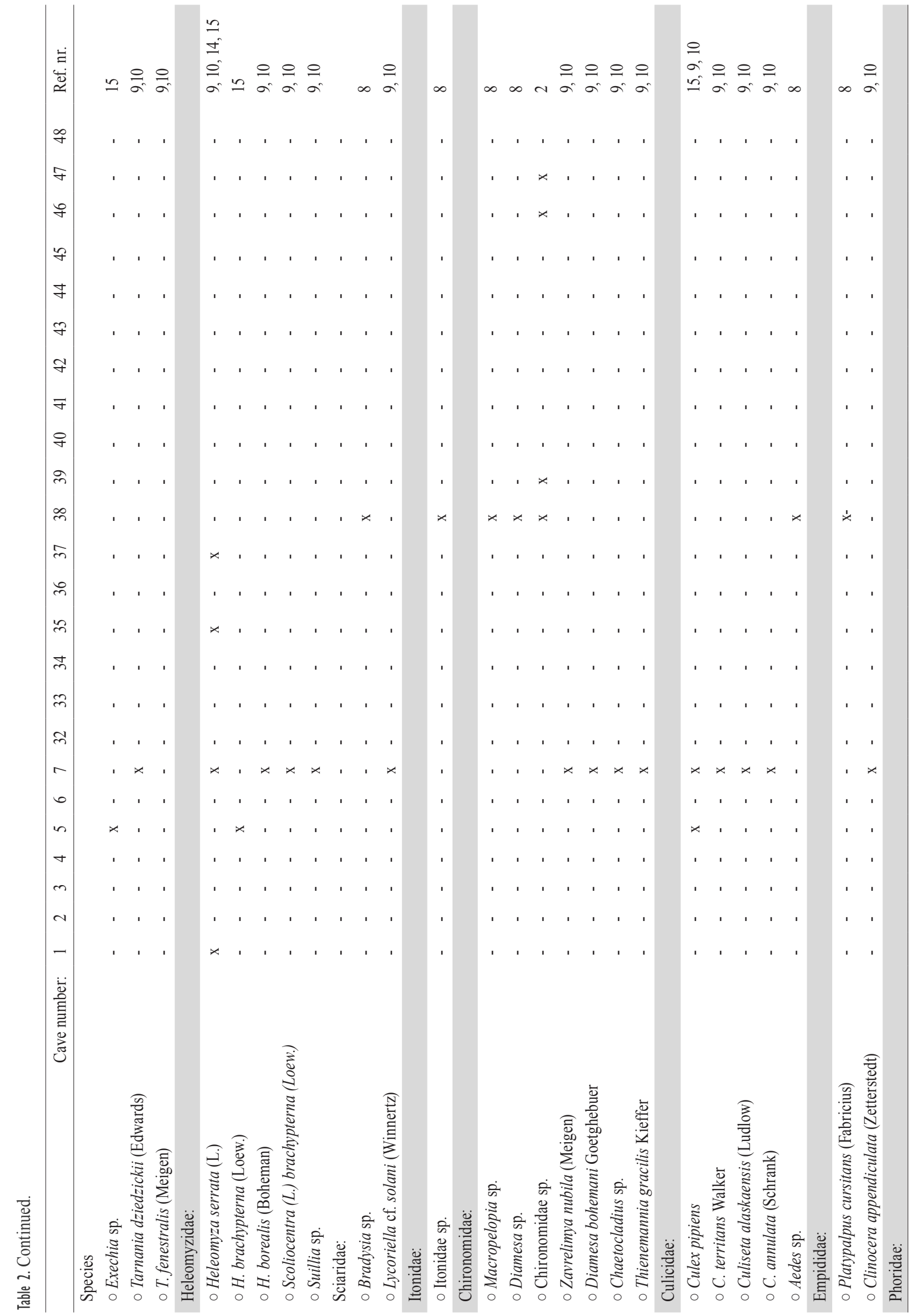




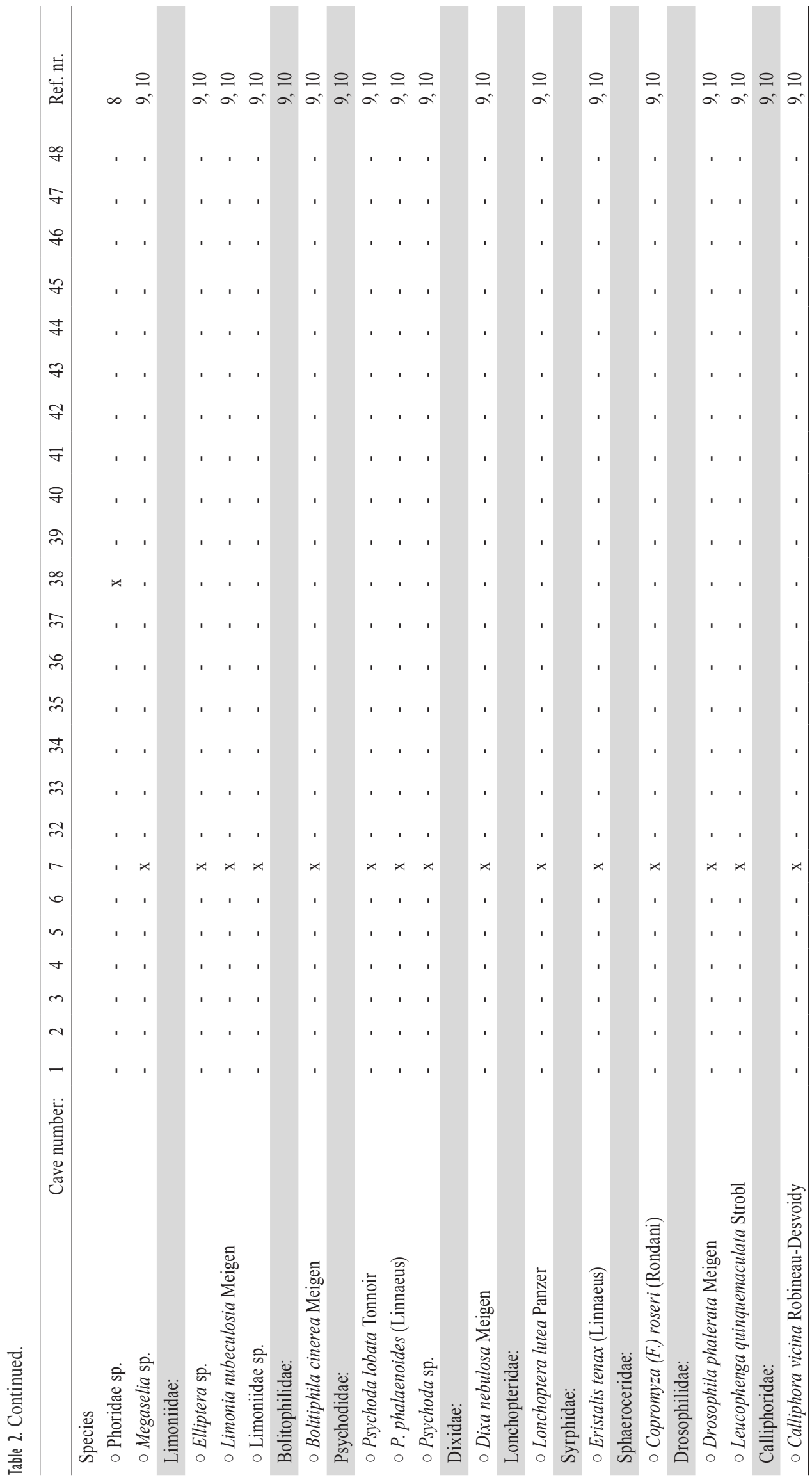


Table 3. The number of species of order Diptera other than family Mycetophilidae from Southwest (SWN) and Southeast Norway (SEN), after Kjærandsen (ref. no. 9 \& 10). $\mathrm{LM}=$ large mines, i.e. $>20 \mathrm{~m}, \mathrm{SM}=$ small mines, i.e. $<20 \mathrm{~m}, \mathrm{CA}=$ cave, $\mathrm{BU}=$ bunkers, $\mathrm{SF}=$ screes and fissures. Symbols as in Table 2.

\begin{tabular}{|c|c|c|c|c|c|c|c|c|}
\hline \multirow{2}{*}{$\begin{array}{l}\text { Family: } \\
\text { Species }\end{array}$} & \multicolumn{5}{|c|}{ SWN } & \multicolumn{3}{|c|}{ SEN } \\
\hline & LM & SM & $\mathrm{CA}$ & $\mathrm{BU}$ & SF & LM & SM & $\mathrm{CA}$ \\
\hline \multicolumn{9}{|l|}{ Tipulidae: } \\
\hline o Dolichopeza albipes Strøm & $\mathrm{x}$ & - & - & - & - & - & - & - \\
\hline \multicolumn{9}{|l|}{ Limoniidae: } \\
\hline o Elliptera sp. & $\mathrm{x}$ & - & - & - & - & - & - & - \\
\hline - Limonia nubeculosia Meigen & $\mathrm{x}$ & - & - & - & - & - & - & - \\
\hline ○ Limoniidae sp. & $\mathrm{x}$ & - & - & - & - & - & - & - \\
\hline \multicolumn{9}{|l|}{ Bolitophilidae: } \\
\hline - Bolitiphila cinerea Meigen & $\mathrm{x}$ & - & - & - & - & - & - & - \\
\hline \multicolumn{9}{|l|}{ Sciaridae: } \\
\hline - Lycoriella cf. solani (Winnertz) & $\mathrm{x}$ & - & - & - & - & - & - & - \\
\hline \multicolumn{9}{|l|}{ Psychodidae: } \\
\hline - Psychoda lobata Tonnoir & - & $\mathrm{x}$ & - & - & $\mathrm{x}$ & - & - & - \\
\hline ○ P. phalaenoides (Linnaeus) & - & $\mathrm{x}$ & - & - & - & - & - & - \\
\hline - Psychoda sp. & - & $\mathrm{x}$ & - & - & - & - & - & - \\
\hline \multicolumn{9}{|l|}{ Trichoceridae: } \\
\hline - Trichocera implicata Dahl & $\mathrm{x}$ & - & - & - & - & - & - & - \\
\hline o T. maculipennis Meigen & $\mathrm{x}$ & - & - & $\mathrm{x}$ & - & - & - & - \\
\hline$\circ$ T. hiemalis (De Geer) & $\mathrm{x}$ & - & - & - & - & - & - & - \\
\hline \multicolumn{9}{|l|}{ Dixidae: } \\
\hline - Dixa nebulosa Meigen & - & - & - & - & - & - & - & $\mathrm{x}$ \\
\hline \multicolumn{9}{|l|}{ Culicidae: } \\
\hline - Culex pipiens Linnaeus & $\mathrm{x}$ & $\mathrm{x}$ & $\mathrm{x}$ & $\mathrm{x}$ & $\mathrm{x}$ & $\mathrm{x}$ & $\mathrm{x}$ & $\mathrm{x}$ \\
\hline o C. territans Walker & $\mathrm{x}$ & $\mathrm{x}$ & $\mathrm{x}$ & - & $\mathrm{x}$ & - & $\mathrm{x}$ & $\mathrm{x}$ \\
\hline - Culiseta alaskaensis (Ludlow) & - & - & - & - & $\mathrm{x}$ & $\mathrm{x}$ & & $\mathrm{x}$ \\
\hline o C. annulata (Schrank) & $\mathrm{x}$ & $\mathrm{x}$ & $\mathrm{x}$ & $\mathrm{x}$ & $\mathrm{x}$ & - & $\mathrm{x}$ & - \\
\hline \multicolumn{9}{|l|}{ Chironomidae: } \\
\hline - Zavrelimya nubila (Meigen) & $\mathrm{x}$ & - & - & - & - & - & - & - \\
\hline - Diamesa bohemani Goetghebuer & - & $\mathrm{x}$ & - & - & - & - & - & - \\
\hline o Chaetocladius sp. & $\mathrm{x}$ & - & - & - & - & - & - & - \\
\hline - Thienemannia gracilis Kieffer & $\mathrm{x}$ & - & - & - & - & - & - & - \\
\hline \multicolumn{9}{|l|}{ Empididae: } \\
\hline - Clinocera appendiculata (Zetterstedt) & $\mathrm{x}$ & - & - & - & - & - & - & - \\
\hline \multicolumn{9}{|l|}{ Lonchopteridae: } \\
\hline - Lonchoptera lutea Panzer & $\mathrm{x}$ & - & - & - & - & - & - & - \\
\hline \multicolumn{9}{|l|}{ Phoridae: } \\
\hline - Megaselia sp. & $\mathrm{x}$ & $\mathrm{x}$ & - & - & - & - & - & - \\
\hline \multicolumn{9}{|l|}{ Syrphidae: } \\
\hline o Eristalis tenax (Linnaeus) & $\mathrm{x}$ & $\mathrm{x}$ & - & $\mathrm{x}$ & - & - & $\mathrm{x}$ & - \\
\hline \multicolumn{9}{|l|}{ Heleomyzidae: } \\
\hline - Scoliocentra (L.) brachypterna (Loew.) & $\mathrm{x}$ & - & $\mathrm{x}$ & - & - & - & - & $\mathrm{x}$ \\
\hline - Heleomyza borealis (Boheman) & $\mathrm{x}$ & - & - & - & - & - & - & - \\
\hline$\circ$ H. serrata (Linnaeus) & $\mathrm{x}$ & $\mathrm{x}$ & $\mathrm{x}$ & $\mathrm{x}$ & $\mathrm{x}$ & $\mathrm{x}$ & & $\mathrm{x}$ \\
\hline o Suillia sp. & $\mathrm{x}$ & - & - & - & - & - & $\mathrm{x}$ & - \\
\hline \multicolumn{9}{|l|}{ Sphaeroceridae: } \\
\hline o Copromyza (F.) roseri (Rondani) & $\mathrm{x}$ & - & - & - & - & - & - & - \\
\hline Drosophilidae: & & & & & & & & \\
\hline - Drosophila phalerata Meigen & $\mathrm{x}$ & - & - & - & - & - & - & - \\
\hline - Leucophenga quinquemaculata Strobl & - & - & - & - & - & - & - & $\mathrm{x}$ \\
\hline Calliphoridae: & & & & & & & & \\
\hline - Calliphora vicina Robineau-Desvoidy & - & - & - & $\mathrm{x}$ & - & - & - & - \\
\hline Number of species & 25 & 9 & 5 & 6 & 6 & 3 & 5 & 7 \\
\hline
\end{tabular}


Table 4. The number of species of the family Mycetophilidae of the order Diptera, from Southwest (SWN) and Southeast Norway (SEN), according to Kjærandsen (ref.no. $9 \&$ 10). $\mathrm{LM}=$ large mines $>20 \mathrm{~m}, \mathrm{SM}=$ small mines, $<20 \mathrm{~m}, \mathrm{CA}=$ caves, $\mathrm{BU}=$ bunkers, $\mathrm{SF}=$ screes and fissures. Symbols as in Table 2.

\begin{tabular}{|c|c|c|c|c|c|c|c|c|}
\hline \multirow[b]{2}{*}{ Species } & \multicolumn{5}{|c|}{ SWN } & \multicolumn{3}{|c|}{ SEN } \\
\hline & LM & SM & $\mathrm{CA}$ & $\mathrm{BU}$ & SF & LM & SM & $\mathrm{CA}$ \\
\hline - Speolepta leptogaster (Winnertz) & $\mathrm{x}$ & $\mathrm{x}$ & - & - & - & $\mathrm{x}$ & $\mathrm{x}$ & $\mathrm{x}$ \\
\hline - Macrobrachius sp. & - & $\mathrm{x}$ & - & - & - & - & - & - \\
\hline - Mycetophila cf. blanda Winnertz & - & $\mathrm{x}$ & - & - & - & - & - & - \\
\hline ○ M. curviseta Lundström & $\mathrm{x}$ & - & - & - & - & - & - & - \\
\hline ○ M. evanida Lastovka & $\mathrm{x}$ & $\mathrm{x}$ & - & - & - & $\mathrm{x}$ & - & - \\
\hline ○ M. ocellus Walker & - & - & - & $\mathrm{x}$ & $\mathrm{x}$ & - & - & - \\
\hline o M. ornata Stephens & $\mathrm{x}$ & $\mathrm{x}$ & - & $\mathrm{x}$ & - & $\mathrm{x}$ & - & - \\
\hline ○ M. ruficollis group & - & - & - & - & & $\mathrm{x}$ & - & - \\
\hline ○ M. signatoides Dziedzicki & $\mathrm{x}$ & $\mathrm{x}$ & - & - & - & - & - & - \\
\hline o $M$. cf. sordida van der Wulp & $\mathrm{x}$ & - & - & - & - & - & - & - \\
\hline o M. unipunctata Meigen & $\mathrm{x}$ & $\mathrm{x}$ & $\mathrm{x}$ & - & $\mathrm{x}$ & - & - & - \\
\hline - Phronia fusciventris Van Duzee & $\mathrm{x}$ & - & - & - & - & - & - & - \\
\hline ○ Phronia sp. & - & - & - & - & - & $\mathrm{x}$ & - & - \\
\hline - Anatella ankeli Plassmann & $\mathrm{x}$ & - & - & - & - & - & - & - \\
\hline$\circ$ Anatella sp. & $\mathrm{x}$ & - & - & - & - & - & - & - \\
\hline - Exechia confinis Winnertz & $\mathrm{x}$ & - & - & - & $\mathrm{x}$ & $\mathrm{x}$ & $\mathrm{x}$ & - \\
\hline o E. contaminata Winnertz & $\mathrm{x}$ & $\mathrm{x}$ & - & - & - & - & - & - \\
\hline o E. cornuta Lundström & $\mathrm{x}$ & $\mathrm{x}$ & $\mathrm{x}$ & - & - & - & - & - \\
\hline o E. dizona Edwards & $\mathrm{x}$ & $\mathrm{x}$ & $\mathrm{x}$ & - & $\mathrm{x}$ & - & $\mathrm{x}$ & - \\
\hline ○ E. exigua Lundström & $\mathrm{x}$ & $\mathrm{x}$ & $\mathrm{x}$ & - & $\mathrm{x}$ & $\mathrm{x}$ & - & - \\
\hline$\circ$ E. festiva Winnertz & $\mathrm{x}$ & $\mathrm{x}$ & $\mathrm{x}$ & $\mathrm{x}$ & $\mathrm{x}$ & - & - & - \\
\hline$\circ$ E. frigida (Boheman) & $\mathrm{x}$ & $\mathrm{x}$ & - & - & - & - & - & - \\
\hline$\circ$ E. fusca (Meigen) & $\mathrm{x}$ & $\mathrm{x}$ & - & $\mathrm{x}$ & $\mathrm{x}$ & - & - & - \\
\hline$\circ$ E. spinigera group & - & $\mathrm{x}$ & - & - & - & - & - & - \\
\hline - Exechiopsis clypeata (Lundström) & $\mathrm{x}$ & - & - & - & - & $\mathrm{x}$ & $\mathrm{x}$ & $\mathrm{x}$ \\
\hline$\circ$ E. distendens (Lackschewitz) & $\mathrm{x}$ & $\mathrm{x}$ & $\mathrm{x}$ & - & - & - & - & - \\
\hline ○ E. dryaspagensis Chandler & $\mathrm{x}$ & - & - & - & - & - & - & - \\
\hline ○ E. fimbriata (Lundström) & $\mathrm{x}$ & $\mathrm{x}$ & $\mathrm{x}$ & - & - & $\mathrm{x}$ & - & - \\
\hline ○ E. hammi (Edwards) & $\mathrm{X}$ & $\mathrm{x}$ & $\mathrm{x}$ & - & - & $\mathrm{x}$ & $\mathrm{x}$ & - \\
\hline$\circ$ E. indecisa (Walker) & $\mathrm{x}$ & - & - & - & $\mathrm{x}$ & $\mathrm{x}$ & - & - \\
\hline ○ E. ingrica (Stackelberg) & - & - & - & - & - & - & - & $\mathrm{x}$ \\
\hline$\circ$ E. intersecta (Meigen) & $\mathrm{x}$ & $\mathrm{x}$ & $\mathrm{x}$ & - & - & $\mathrm{x}$ & - & - \\
\hline$\circ$ E. januarii (Lundström) & - & - & - & - & - & $\mathrm{x}$ & $\mathrm{x}$ & $\mathrm{x}$ \\
\hline ○ E. lackschewitziana (Stackelberg) & $\mathrm{x}$ & - & - & - & - & - & $\mathrm{x}$ & $\mathrm{x}$ \\
\hline ○ E. januarii (Lundström) & $\mathrm{x}$ & - & - & - & - & - & - & - \\
\hline ○ E. ligulata (Lundström) & $\mathrm{x}$ & - & $\mathrm{x}$ & - & - & $\mathrm{x}$ & - & - \\
\hline o E. pseudindecisa Lastovka \& Matile & - & - & - & - & - & $\mathrm{x}$ & - & - \\
\hline$\circ$ E. pseudopulchella (Lundström) & $\mathrm{x}$ & $\mathrm{x}$ & $\mathrm{x}$ & - & - & - & - & - \\
\hline ○ E. subulata (Winnertz) & $\mathrm{x}$ & $\mathrm{x}$ & $\mathrm{x}$ & - & - & $\mathrm{x}$ & - & $\mathrm{x}$ \\
\hline$\circ$ E. (X.) pollicata (Edwards) & $\mathrm{x}$ & - & - & - & - & $\mathrm{x}$ & - & - \\
\hline - Pseudexechia aurivernica Chandler & $\mathrm{x}$ & $\mathrm{x}$ & $\mathrm{x}$ & $\mathrm{x}$ & $\mathrm{x}$ & - & - & - \\
\hline ○ P. trisignata (Edwards) & $\mathrm{x}$ & - & $\mathrm{x}$ & - & $\mathrm{x}$ & - & - & - \\
\hline ○ Rymosia affinis Winnertz & $\mathrm{x}$ & $\mathrm{x}$ & $\mathrm{x}$ & $\mathrm{x}$ & - & - & - & - \\
\hline$\circ$ R. fasciata (Meigen) & $\mathrm{x}$ & $\mathrm{x}$ & $\mathrm{x}$ & $\mathrm{x}$ & $\mathrm{x}$ & $\mathrm{x}$ & $\mathrm{x}$ & $\mathrm{x}$ \\
\hline$\circ$ R. placida Winnertz & $\mathrm{x}$ & $\mathrm{x}$ & - & - & - & $\mathrm{x}$ & $\mathrm{x}$ & - \\
\hline ○ R. cf. Winnertzi Barendrecht & $\mathrm{x}$ & - & - & - & - & - & - & - \\
\hline - Tarnania dziedzickii (Edwards) & $\mathrm{x}$ & $\mathrm{x}$ & - & - & - & - & - & - \\
\hline$\circ$ T. fenestralis (Meigen) & $\mathrm{x}$ & - & - & - & - & - & - & - \\
\hline Number of species & 39 & 26 & 16 & 7 & 12 & 19 & 9 & 7 \\
\hline
\end{tabular}


Table 5. Class, order and number of species recorded in Norwegian caves and mines.

\begin{tabular}{lc}
\hline Taxa & Number of species \\
\hline Class Gastropoda: & \\
Order Stylomatophora & 6 \\
Class Clitellata: & \\
Order Oligochaeta & 2 \\
Class Arachnidae: & \\
Order Araneae & 8 \\
Order Acari & 8 \\
Class Cladocera & 5 \\
Class Copepoda & 7 \\
Class Amphipoda & 1 \\
Class Collembola & 25 \\
Class Insecta: & \\
Order Ephemeroptera & 12 \\
Order Plecoptera & 21 \\
Order Trichoptera & 6 \\
Order Coleotera & 38 \\
Order Lepidoptera & 2 \\
Order Diptera & 103 \\
\hline Total & 244 \\
\hline
\end{tabular}

\section{RESULTS AND DISCUSSION}

In total, 244 species were recorded from 14 taxa. Insecta and Collembola together dominates with $85 \%$ of recorded species; Diptera alone stand for $42 \%$. In general, the invertebrate fauna of Norwegian caves are poor in species diversity compared to the fauna in caves further south in Europe due to the more severe and harsh climatic regime at high latitudes (Østbye et al. 1987). Multiple glacial-interglacial cycles during the Pleistocene period would expectedly have implications for the faunal history of our caves, with less suitable conditions prevailing during long periods of glaciations. It is likely that many of the caves may have been completely water-filled (subglacial) during stadials and hence unsuitable for terrestrial animals.

In caves of the Open systems types all faunal components belonging to the upstream limnic ecosystems, lakes, ponds, rivers or brooks can be found, brought in with running water. The surface or surface-related forms may survive for a period but rarely reproduce underground, even if they are able to run through some stages of their life cycle in underground environments. Most of the water-drifting forms have to be classified as accidental or habitual trogloxenes (Hippa et al. 1985; Østbye et al. 1987; Dolmen \& Arnekleiv 1990; Arnekleiv \& Dolmen 1992), even if some species are supposed to be permanent inhabitants, troglophiles. Little attention, however, has been paid to the fauna of this category of caves, as very few cavernicoles (troglobites) have been found. Only in one open-system cave, in south Norway, a stable population of a cavernicolous crustacean, the troglobite population of
Gammarus lacustris is known (Østbye et al. 1987; Lien 1997; Lien, Østbye \& Østbye 1996). This species display several of the typical traits for cave adaption. In addition, the phylogeographic history (based on unpublished investigations of mtDNA) of this caveliving population suggests that it has immigrated to the area from refugia most likely situated in southern Europe, the Alps. This immigration appears to have taken place long before the presumed post-glacial immigration of the surface-living populations of G. lacustris which are found in adjacent lakes in the area. Furthermore their origin of the latter immigration is likely from the east, the Siberian area in Russia.

In caves of the Infiltration systems types, several examples on more complex and stable cave ecosystems are found. Possibly due to the northern location and the glacial history (and the age of the caves) of Norway, no faunal inhabitant in the caves of the Infiltration system type can be classified as a true troglobite. Only a few troglophiles have been found, most of the recorded species must be classified as trogloxenes, accidental or habitual.

All the six recorded species of Gastropoda must be characterised as accidental trogloxenes, as the both recorded species of Clitellata. Three of the eight recorded species of Arachnida, Aranea, could be classified as troglophiles, the other species as trogloxenes, most probably accidental ones, even those marked with + . Of the nine recorded species (or taxa) of Arachnida, Acari, five could be characterised as troglophiles, one as trogloxene, while three were uncertain in classification. One of the 13 recorded species of the Crustacea could be classified as a real troglobite, the amphipod Gammarus lacustris with a permanent population in cave no. 2. The specimens in cave no. 48 are drift. All the other species were accidental trogloxenes.

Five of the recorded 25 species of the Collembola could be classified as troglophiles, while all the 20 other species were (probably) accidental trogloxenes. All of the 12 recorded species of the order Ephemeroptera has to be classified as accidental trogloxenes, as all the 21 recorded species of the order Plecoptera, together with the six recorded species of the order Trichoptera. Of the recorded 38 species of the order Coleoptera 14 could be classified as troglophiles, while the others were trogloxenes, most probably accidental, but some may be habitual ones. Of the order Lepidoptera both recorded species are habitual trogloxenes, entering caves for hibernation. Three of the recorded species of the order Diptera could be classified as troglophiles, of which Speolepta leptogaster is the most typical one. All the other species are trogloxenes.

Kjærandsen $(1992,1993)$ has the following classification for the registered species of the order Diptera:

A. Troglophiles of which larvae live in underground environments: Speolepta leptogaster.

B. Habitual trogloxenes:

1. Hibernators 
a. Species where both sexes hibernate underground and mating takes place in the following spring (Mycetophilidae).

b. Species where mating takes place prior to hibernation and only females are found underground during winter (Culicidae).

2. Aestivators

a. Species where both sexes seek cave systems during summer (Limoniidae).

b. Species where mating takes place prior to aestivation and only females are found underground in summer (Bolitophilidae).

3. Species which seek cave systems independent of sex and season (Helomyzidae, Trichoceridae).

4. Opportunists (Chironomidae, Phoridae?)

\section{Accidental trogloxenes (most other Diptera).}

The study Kjærandsen has conducted $(1992,1993)$ is one of the best carried out on cavedvelling Diptera, and we regard his classification as the best one for the Nordic caves and mines.

\section{REFERENCES}

Numbers in front refer to paper reference in tables.

1. Arnekleiv JV, Dolmen D. 1992. Ferskvannsinvertebrater i noen nord-norske kalksteinsgrotter. Entomologisk Tidskrift 113: $15-26$

2. Dolmen D, Arnekleiv JV. 1990. En zoologisk befaring av karstområder og grottesystemer i Grane og Rana kommuner, Nordland. Universitetet i Trondheim, Vitenskapsmuseet, Rapport, Zoologisk serie, 1990-2: 45 p.

Heaton T. 1986. A tremendous Range in Energy Environments on Earth. National Speleological Society News 44(8): 301-304.

3. Hippa H, Koponen S, Mannila R. 1984. Invertebrates of Scandinavian caves I. Araneae, Opiliones, and Pseudoscorpionida (Arachnida). Annales Entomologici Fennici 50: 23-29.

4. Hippa H, Koponen S, Mannila S. 1985. Invertebrates of Scandinavian caves III. Ephemeroptera, Plecoptera, Trichoptera, and Lepidoptera. Notulae Entomologicae 65: 25-28.

5. Hippa H, Koponen S, Mannila R, Biström O. 1985. Invertebrates of Scandinavian caves IV. Coleoptera. Notulae Entomologicae 65: 73-80.

6. Hippa H, Koponen S, Mannila R, Vilkamaa P 1988. Invertebrates of Scandinavian caves VI. Collembola. Notulae Entomologicae 68: $1-5$.

7. Hippa H, Koponen S, Mannila R, Niemi R,Uusitalo M. 1988. Invertebrates of Scandinavian caves VII. Acari. Notulae Entomologicae, 68: 141-146.

8. Hippa H, Koponen S. 1988. The Arthropod Fauna of Grønligrotta, Norway. Cave Science 15: 117-119.

9. Kjærandsen J. 1992. Hulelevende tovinger, med hovedvekt på soppmygg (Diptera: Mycetophilidae). Unpublished Cand.scient. thesis, Zoological museum, University of Bergen, Norway, 67 p.
(In Norwegian and English).

10. Kjærandsen J. 1993. Diptera in mines and other cave systems in southern Norway. Entomologica Fennica 4: 151-160.

Lauritzen S-E. 2010. Grotter. Norges ukjente underverden. Oslo. Tun Forlag. $240 \mathrm{p}$.

11. Lauritzen S-E, Østbye E. 1994. Norway. In: Juberthie, C and Decu, V (eds.). Encyclopedia Biospeologica. Societe de biospeologie, Moulis-Bucarest vol.1. pp 761-766.

12. Lien A. M. 1997. Sammenligning av en grottepopulasjon av marflo, Gammarus lacustris G. O. Sars med hensyn på morfologi og livshistorie. Unpublished Cand.Scient.thesis, Biological institute, University of Oslo, 89 p. (In Norwegian).

13. Lien AM, Østbye K, Østbye E. 1996. Life cycle and morphology of an epigean and a hypogean population of Gammarus lacustris G. O. Sars (Amphipoda) in South Norway. Karst Waters Special Publication 2: 97-100.

14. Natvig LR. 1923. Hammernesgrotterne ved Langvandet. Den Norske Turistforenings aarbok 1923: 1-17.

15. Østbye E, Lauritzen S-E, Fjellberg A, Hauge E, Leinaas HP, Ottesen P, Solhøy T. 1987. Invertebrates of Norwegian caves I. Gastropoda, Oligochaeta, Araneae, Acari, Amphipoda, Collembola, Coleoptera, Lepidoptera and Diptera. Fauna norvegica Serie A 8: $43-64$.

Werker HV, Werker JC (eds.). 2006. Cave conservation and restoration. National Speleological Society, Huntsville, Ala. USA. $600 \mathrm{p}$.

Editorial responsibility: Torkild Bakken.

This article is open-access and distributed under the terms of the Creative Commons Attribution-Noncommercial 3.0 Unported License (http://creativecommons.org/licenses/by-nc/3.0/). This permits all non-commercial use, distribution, and reproduction in any medium, provided the original work is properly cited. 